\title{
MANAJEMEN PENDIDIKAN KELUARGA: Perspektif Al-Qur'an Menjawab Urban Middle Class Milenial
}

\author{
Zulkifli Syauqi Thontowi $^{1}$, Ahmad Syafii ${ }^{2}$, Achmad Dardiri ${ }^{3}$ \\ ${ }^{1}$ Pascasarjana Universitas Negeri Yogyakarta \\ ${ }^{2}$ Pascasarjana UIN Sunan Kalijaga Yogyakarta \\ ${ }^{3}$ Dosen Pascasarjana Universitas Negeri Yogyakarta \\ e-mail: zulkiflisyauqi@gmail.com \\ e-mail: azfy99@gmail.com \\ e-mail: achmaddardiri@uny.ac.id
}

Received:08/02/2019, Accepted: 20/02/2019, Published: 25/02/2019

\begin{abstract}
In the midst of this disruption era, Family is one of the keys to the success of Education. Family becomes an organic basis Education for the development of a child. In the family a child is formed physically and psychologically. This paper aims to explore the perspective of the Qur'an in seeing family education as a whole. The millennial era, which was marked by the development of super-fast technology and information, made socio-culture in the family change a lot. The rolling 4.0 industrial revolution cannot be sustained amid the pace of globalization. The results of the discussion indicate that a new approach is needed in family education amid the ongoing changes.
\end{abstract}

Keywords: family education, urban midle class millennial.

\begin{abstract}
ABSTRAK
Di tengah era disrupsi ini, Keluarga adalah salah satu kunci suksesnya Pendidikan. Keluarga menjadi basis organik Pendidikan bagi perkembangan seorang anak. Dalam keluarga seorang anak dibentuk fisik dan psikisnya. Tulisan ini bertujuan untuk mengeksplor perspektif Al-Qur'an dalam melihat pendidikan keluarga secara utuh. Era milenial yang ditandai dengan perkembangan tekhnologi dan informasi yang super cepat menjadikan sosio-kultur dalam keluarga banyak berubah. Revolusi industri 4.0 yang bergulir tidak dapat ditahan di tengah laju globalisasi. Hasil pembahasan menunjukkan bahwa dibutuhkan pendekatan baru dalam pendidikan keluarga di tengah perubahan yang terus terjadi.
\end{abstract}

\section{A. PENDAHULUAN}

Akhir-akhir ini banyak berkembang isu kenakalan remaja. Kasus kenakalan remaja seperti perkelahian antar siswa, bullying antar siswa baik berupa bullying verbal maupun non verbal, kekerasan yang dilakukan oleh siswa terhadap guru yang akhir-akhir ini marak terjadi bahkan hingga sampai pembunuhan, narkoba, dan kasus-kasus lainnya menjadi masalah yang saat ini menghantui bangsa kita. 


\section{Manajemen Pendidikan Keluarga...}

Problematika itu tentu tidak muncul begitu saja. Keluarga sebagai basis utama dalam pengembangan kepribadian anak adalah salah satu point of view dalam melihat kasus-kasus yang terjadi akhirakhir ini. Keluarga merupakan salah satu isu penting dalam pembangunan nasional. Suatu masyarakat terbentuk dari kelompok-kelompok keluarga. Jika keluarga sebagai pembentuk masyarakat itu sehat dan kuat, maka suatu negara akan sehat dan kuat pula. Begitu pula sebaliknya apabila keluarganya sakit dan lemah, maka suatu negara akan lemah dan sakit pula. Dalam Islam keluarga dipandang sebagai pusat peradaban Islam dan pengembangan masyarakat.

Dalam bahasa Arab kata keluarga disebut ahl atau ahila yang berarti keluarga secara menyeluruh termasuk kakek, nenek, paman, bibi, dan keponakan. Dalam pengertian yang luas tersebut keluarga dalam Islam merupakan satu kesatuan unit yang besar yang disebut Ummah komunitas umat Islam.

Keluarga Islami tidak hanya dipandang atas kenyataan karena sering terdengar lantunan ayat Al-Qur'an dari rumah tersebut. Bukan pula sekedar anakanaknya yang disekolahkan ke masjid di waktu sore hari. Keluarga Islami adalah keluarga yang di dalamnya ditegakkan adab-adab Islami. Islami adalah keluarga yang dibangun atas landasan ibadah mereka bertemu dan berkumpul karena Allah. Saling menasihati dalam kebenaran dan kesabaran.

Keluarga sebagai pendeta dalam membentuk generasi bangsa dan agama. Di sinilah peran penting pendidikan agama harus tertanam sejak awal di dalam keluarga. Untuk itu, maka pendidikan dalam keluarga harus dikembangkan dengan baik.

Berangkat dari kegelisahan di atas, penulis kemudian menginginkan bagaimana nilai-nilai yang terkandung di dalam Al-Qur'an sebagai sumber utama pedoman manusia hidup memandang keluarga sebagai basis pendidikan. Di dalam Al-Qur'an terdapat banyak sekali ayat-ayat yang berhubungan dengan pendidikan keluarga. Akan tetapi karena keterbatasan ruang penulisan ini, penulis lebih menypesifikasi pada kajian tafsir Surat At-Tahrim Ayat 6. Diharapkan dengan adanya makalah ini memberikan satu tawaran terhadap pemaknaan AlQur'an Surat At-Tahrim Ayat 6 tersebut di tengah masyarakat era milenial saat ini.

Tafsir Ayat tentang Pedidikan Keluarga

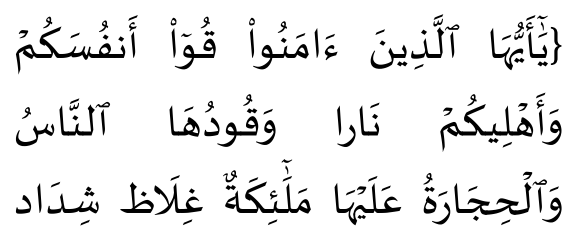


لَّلَ يَعُصُونَ آللَّلَهَ مَاَ أَمَرَهُمْ وَيَفْعَلُونَ

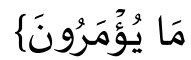

"Hai orang-orang yang beriman, peliharalah dirimu dan keluargamu dari api neraka yang bahan bakarnya adalah manusia dan batu; penjaganya malaikatmalaikat yang kasar, keras, dan tidak mendurhakai Allah terhadap apa yang diperintahkan-Nya kepada mereka dan selalu mengerjakan apa yang diperintahkan”. (Q.S.

\section{At-Tahrim: 12)}

Surat At-Tahrim terdiri atas 12 ayat, dan merupakan Surat ke 66 dalam AlQur'an yang diturunkan setelah surat AlHujurat. Surat ini masuk dalam golongan surat madaniyah, yaitu surat yang diturunkan ketika Nabi Muhammad S.A.W. sudah berada di Madinah. Surat ini dinamakan At-Tahrim karena pada awal surat ini terdapat kata tuharrim yang berasal dari kata At-Tahrim yang artinya mengharamkan.

Di dalam kandungan surat ini meliputi keimanan, hukum, dan kisah. Dalam aspek keimanan ayat ini, menjelaskan tentang kesempatan bertobat hanya ada di dunia saja. Dan segala amal perbuatan manusia di dunia akan dibalas di akhirat kelak. Dalam aspek hukum, ayat ini menjelaskan tentang larangan untuk mengharamkan apa yang dihalalkan oleh Allah, kewajiban membebaskan diri dari sumpah yang diucapkan untuk mengharamkan yang halal dengan membayar kafarat, kewajiban memelihara diri dan keluarga dari api neraka, perintah memerangi orang-orang kafir dan munafik dan berlaku keras terhadap mereka di waktu perang. Adapun dalam aspek kisah, surat ini menceritakan tentang kisah istri nabi Luth, istri nabi Nuh, istri Firaun, dan Maryam. ${ }^{1}$

Ayat di atas, menjelaskan tentang keluarga sebagai objek pendidikan pertama dan utama dalam membentuk karakter peserta didik. Dalam tafsir AlMaraghi disebutkan, bahwa pengertian secara ijmal dari ayat tersebut adalah sebagai berikut. Ayat tersebut diturunkan khususnya kepada sebagian dari istri Nabi Muhammad untuk bertobat dari kesalahan yang terlanjur telah dilakukan dan menjelaskan kepada mereka bahwa Allah akan menjaga dan menolong rasul-Nya tujuan kerja sama mereka untuk menyakiti tidak akan membahayakan. Kemudian memperingatkan mereka agar tidak berkepanjangan dalam menentang karena khawatir akan dikalahkan dijatuhkan dari

${ }^{1}$ H. Ahmad Izzan dan S. Saehudin. (2012). Tafsir Pendidkan: Studi Ayat-Ayat Berdimensi Pendidikan (Jakarta: Pustaka Aufa Media. hlm. 210-11. 


\section{Manajemen Pendidikan Keluarga...}

kedudukannya yang mulia sebagai ibu-ibu kaum Mukminin. ${ }^{2}$

Makna dari ayat tersebut adalah bahwa Allah memerintahkan kepada umatnya yang beriman untuk menjaga diri mereka dari api neraka dan menjauhkan darinya. Di samping itu, ayat ini juga memerintahkan untuk mengajarkan kepada keluarga perbuatan yang dapat menjaga diri dari api neraka. Juga dalam mengajarkan menjaga diri dari api neraka dengan nasihat dan pengajaran.

Dalam tafsir Al-Maraghi dijelaskan, bahwa ayat di atas semakna dengan ayat dalam firman Allah:

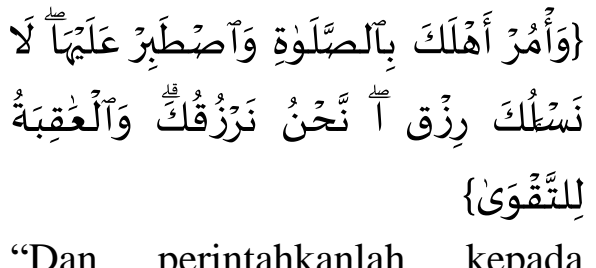

keluargamu mendirikan Shalat dan bersabarlah kamu dalam mengerjakannya. Kami tidak meminta rezeki kepadamu, Kamilah yang memberi rezeki kepadamu. Dan akibat (yang baik) itu adalah bagi orang yang bertakwa”. (Q.S. Thâhâ/20:132)

Telah diriwayatkan bahwa Umar berkata ketika turunnya ayat tersebut:

"Wahai Rasulullah, kita menjaga diri kita sendiri. Tetapi bagaimana

2 Ahmad Mushthafa Maraghi dkk., (1987). Terjemah Tafsir Al-Maraghi. Semarang: C.V. Toha Putra. kita menjaga keluarga kita?" Rasulullah pun menjawab," kamu larang mereka mengerjakan apa yang dilarang Allah untukmu, dan kamu perintahkan kepada mereka apa yang diperintahkan Allah kepadamu. Itulah penjagaan antara diri mereka dengan neraka

Telah dikeluarkan oleh Ibnu AlMundzir dan Al-Hakim di dalam jamaah akharin, Ali karromallohu wajhah, bahwa dia mengatakan tentang ayat itu," ajarilah dirimu dan keluargamu kebaikan dan didiklah mereka ".

Dalam perspektif tafsir al-maraghi, makna al-ahl (keluarga) di sini mencakup istri, anak, budak laki-laki dan budak perempuan. Kata "qu anfusakum" yang berarti: Buatlah sesuatu yang dapat menjadi penghalang datangnya siksaan api neraka dengan cara menjauhkan perbuatan maksiat. Memperkuat diri agar tidak mengikuti hawa nafsu dan senantiasa taat menjalankan perintah Allah. Kemudian alwaqud adalah sesuatu yang dapat dipergunakan untuk menyalakan api. Sedangkan al-hijarah adalah batu berhala yang biasa di sembah oleh masyarakat jahiliah. Malaikatun dalam ayat tersebut maksudnya mereka yang jumlahnya sebanyak 19 dan bertugas menjaga neraka. Sedangkan ghiladzun maksudnya adalah hati yang keras, yaitu hati yang tidak memiliki rasa belas kasihan apabila ada yang meminta dikasihani. Dan syidadun 
artinya memiliki kekuatan yang tidak dapat dikalahkan.

Di dalam ayat ini terdapat isyarat, mengenai kewajiban seorang suami mempelajari fardu yang diwajibkan baginya dan mengajarkannya kepada mereka.

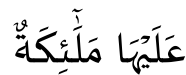

Maksud dari bagian ayat tersebut, bahwa malaikat-malaikat itu diserahi neraka dan untuk mengurusnya serta menyiksa para penghuninya. Jumlah malaikat-malaikat ini ada 19 orang malaikat penjaga neraka yang akan disebutkan dalam Surat Al-Muddatsir bahawa Allah berfirman:

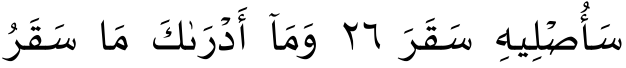

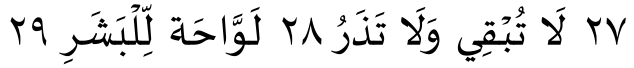

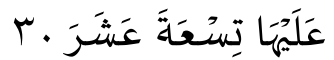

“Aku akan memasukkannya ke dalam (neraka) Saqar. Tahukah kamu apakah (neraka) Saqar itu. Saqar itu tidak meninggalkan dan tidak membiarkan. (Neraka Saqar) adalah pembakar kulit manusia. Dan di atasnya ada sembilan belas (malaikat penjaga)". (Q.S. AlMuddatsir [74]: 26-30)

$$
\text { غِلَاظ شِدَاد }
$$

Dalam ayat tersebut dijelaskan, bahwa para malaikat keras dan kasar terhadap para penghuni neraka itu.

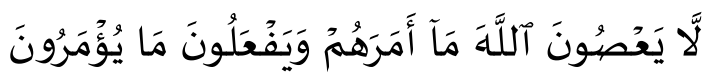

Mereka (malaikat) tidak menyalahi perintah Allah, tetapi mereka menjalankan apa yang diperintahkan kepada mereka pada waktu itu juga tanpa selang waktu. Mereka tidak mendahului atau pun menunda perintah Allah. Pada kalimat pertama menunjukkan penafian, penentangan dan kesombongan dari mereka. Sedangkan pada kalimat kedua menunjukkan penafian kemalasan dari mereka.

Jika dilihat dari tafsir Al-Wasith makna Surat At-Tahrim Ayat 6 di atas adalah orang-orang yang membenarkan Allah dan rasul-Nya diberi perintah untuk melatih diri dan keluarga untuk melakukan amal kesalehan. Kita diperintahkan untuk membuat perlindungan bagi semua dari api neraka, untuk diri sendiri dengan menjadikan selalu dalam ketaatan terhadap Allah. Sedangkan untuk keluarga dengan cara memberikan nasihat kepada mereka dan juga mendorong mereka untuk melakukan ketaatan. Hal ini karena tidak akan terjerumus bersama-sama ke dalam api neraka yang mengerikan, yang dinyalakan dengan manusia dan batu, sebagaimana api yang dinyalakan dengan kayu bakar. Hal ini menjadi dalil bahwa seorang pengajar seharusnya mengetahui apa yang diperintahkan oleh Allah dan yang dilarang oleh Allah. 


\section{Manajemen Pendidikan Keluarga...}

Neraka dijaga oleh para malaikat yang sangat kasar perangai dan tabiatnya. Yang keras hatinya, kejam, bengis, dan memiliki kekuatan yang luar biasa. Makna kata Asy-Syiddah adalah jumlah malaikat Zabaniah sebagai penjaga neraka ada 19. Mereka memiliki keistimewaan berupa ketaatan sempurna kepada Allah, sehingga mereka tidak mendurhakai segala perintah Allah. Mereka selalu menunaikan apa pun yang diperintahkan oleh Allah.

Di dalam tafsir Tarbawi dijelaskan secara tegas Ayat 6 Surat At-Tahrim di atas, mengingatkan semua orang mukmin agar mendidik diri dan keluarganya ke jalan yang benar agar terhindar dari neraka. Ayat tersebut mengandung perintah menjaga yaitu kalimat "qu" yang berarti jagalah. Perintah menjaga diri dan keluarga dari neraka berkonotasi terhadap perintah mendidik dan membimbing. Sebab pendidikan dan bimbingan yang dapat membuat diri dan keluarga konsisten dalam kebenaran, di mana konsisten dalam kebenaran ini membuat orang terhindar dari siksa api neraka. Untuk itu maka para orang tua berkewajiban mengajarkan kebaikan dan ajaran agama kepada anakanaknya. Menyuruh mereka untuk berbuat kebajikan dan menjauhkan kemungkaran dengan cara membiasakan berbuat kebenaran atau kebaikan tersebut, selain itu juga memberikan contoh yang baik terhadap anak-anaknya.

Ayat 6 tersebut juga menggambarkan keadaan api neraka. Ada dua kondisi neraka yang digambarkan dalam ayat tersebut pertama, adalah bahan bakarnya. Terdiri dari manusia dan batu. Manusia yang akan menjadi bahan bakar neraka tersebut adalah orang-orang kafir. Dan menurut sebagian mufasir, batu yang dijadikan sebagai bahan bakar neraka itu adalah berhala yang mereka sembah. Kedua, neraka itu dijaga oleh malaikat yang amat kasar dan keras terhadap penghuni neraka. Makhluk ini sangat patuh kepada Allah serta tidak pernah melanggar perintah Allah.

Pengertian tentang pentingnya membina keluarga agar terhindar dari siksaan api neraka ini tidak hanya sematamata diartikan api neraka yang ada di akhirat kelak, melainkan juga termasuk berbagai masalah dan bencana yang menyedihkan, merugikan dan merusak citra pribadi seseorang. Sebuah keluarga yang anaknya terlibat dalam berbagai perbuatan tercela seperti mencuri, merampok, menipu, berzina, meminum minuman keras, terlibat narkoba, membunuh, dan sebagainya adalah termasuk dalam hal-hal yang dapat menciptakan bencana di muka bumi dan merugikan orang yang melakukannya. Hal 
itu termasuk perbuatan yang dapat membawa bencana. Keluarga, istri, anak, menantu, adik, dan sebagainya dapat menjadi musuh dan membawa malapetaka apabila terlibat dalam perbuatan tersebut.

Lebih jauh Abdullah Nashih Ulwan menjelaskan, tentang tujuan pendidikan dalam hal ini ia mengatakan bahwa pendidikan itu tidak hanya sekedar memanusiakan manusia akan tetapi dengan jelas dan rinci yang menyebutkan sebagai upaya membina mental, melahirkan generasi, membina umat, serta memperlakukan prinsip-prinsip kemuliaan dan peradaban. ${ }^{3}$

Hal yang sedikit berbeda dikemukakan dalam tafsir Al-Misbah karangan Prof. Quraish Shihab. Dalam tafsir tersebut, dijelaskan bahwa ayat 6 di atas menggambarkan bahwa dakwah dan pendidikan harus bermula dari rumah. Ayat di atas secara redaksional tertuju kepada kaum pria (ayah), akan tetapi itu bukan berarti hanya ditujukan kepada mereka. Ayat ini tertuju kepada perempuan dan lelaki (ibu dan ayah) sebagaimana ayat-ayat yang serupa (misalnya ayat yang memerintahkan berpuasa) yang juga tertuju kepada lelaki dan perempuan. Ini memiliki implikasi bahwa kedua orang tua bertanggung jawab

\footnotetext{
${ }^{3}$ Izzan dan Saehudin, Tafsir Pendidkan. hlm. 212.
}

atas kelakuannya. Ayah atau Ibu sendiri tidak cukup untuk menciptakan suatu rumah tangga yang diliputi oleh nilai-nilai agama serta dinaungi oleh hubungan yang harmonis. ${ }^{4}$

Bahwa manusia menjadi bahan bakar neraka, dipahami oleh Thabathaba'i dalam arti manusia terbakar dengan sendirinya. Menurutnya ini sejalan dengan Al-Qur'an surat Al-Mukmin Ayat 72.

Malaikat yang disifati dengan kata ghiladz bukankah dalam arti kasar jasmaniah seperti dalam beberapa kitab tafsir lainnya, hal ini karena malaikat adalah makhluk halus yang tercipta dari cahaya. Atas dasar ini kata tersebut harus dipahami dalam arti kasar perilakunya atau ucapannya. Mereka telah diciptakan Allah khusus untuk menangani neraka. Hati mereka tidak iba atau tersentuh oleh rintihan, tangis, atau permohonan belas kasihan, mereka diciptakan Allah dengan sifat sadis dan karena itulah maka mereka syidad/keras yaitu makhluk yang keras hatinya dan keras pula perilakunya.

\section{B. IMPLIKASI \\ AYAT-AYAT PENDIDIKAN KELUARGA}

Banyak ahli yang memberikan pendapat mengenai pengertian pendidikan keluarga. Mansyur mendefinisikan

\footnotetext{
${ }^{4}$ M. Quraisy Syihab. (2012). Tafsir Al-
} Misbah, Pesan, Kesan, Keserasian Al-Quran, vol. 14, Jakarta: Lentera Hati. hlm. 326. 


\section{Manajemen Pendidikan Keluarga...}

pendidikan keluarga adalah proses pemberian nilai-nilai positif bagi tumbuh kembangnya anak sebagai fondasi pendidikan selanjutnya. Dalam definisi lain, Abdullah memberikan pengertian pendidikan keluarga bahwa segala usaha yang dilakukan oleh orang tua berupa pembiasaan dan improvisasi untuk membantu perkembangan pribadi anak. Hasan langgulung sendiri memberi batasan terhadap pengertian pendidikan keluarga adalah usaha yang dilakukan oleh ayah dan ibu sebagai orang yang diberi tanggung jawab untuk memberikan nilainilai, akhlak, keteladanan, dan kefitrahan. ${ }^{5}$

Ki Hajar Dewantara memberikan pemaknaan yang lain bahwa alam keluarga bagi setiap anak adalah alam pendidikan permulaan. Dia yang merupakan salah satu tokoh pendidikan Indonesia mengemukakan bahwa di dalam keluarga untuk pertama kalinya orang tua baik ayah maupun ibu berkedudukan sebagai penuntun, guru sebagai pengajar, sebagai pendidik, pembimbing, dan sebagai pendidik utama bagi anak. Hal ini, maka dapat ditarik bahwa tidak berlebihan apabila pendidikan keluarga tidak hanya sekedar tindakan saja akan tetapi ia hadir dalam praktik dan implementasi yang dilaksanakan orang tua dengan nilai pendidikan terhadap keluarga.

Dalam tafsir ayat di atas, implikasi yang harus dilakukan oleh keluarga ialah menjadikan keluarga sebagai ruang pendidikan yang utama. Ki Hajar Dewantara meletakkan pendidikan keluarga sebagai bagian dari Tri Pusat Pendidikan, yaitu keluarga, sekolah, dan masyarakat. Pada hakikatnya fungsi keluarga adalah sebagai pendidik budi pekerti, sosial, kewarganegaraan, pembentukan, pembiasaan, dan pendidikan intelektual anak.

Abdullah membagi tiga fungsi keluarga dalam pendidikan anak yaitu:

1. Fungsi kuantitatif

Maksudnya adalah keluarga menjadi penyedia bagi pembentukan perilaku dasar. Artinya keluarga tidak hanya menyediakan kebutuhan dasar fisik baik berupa pakaian, makanan dan minuman, serta tempat tinggal yang layak. Akan tetapi keluarga juga dituntut untuk menyediakan dan membuat iritasi ketersediaan dasardasar kebaikan, mengubah perilaku, etika, sopan santun, dan pembentukan karakter anak yang santun dan berakhlak baik sebagai fitrah manusia yang hakiki. 
2. Fungsi selektif

Maksudnya adalah keluarga menjadi tempat menyaring pengalaman anak dan ketidaksamaan posisi kemasyarakatan karena lingkungan. Artinya pendidikan keluarga promosi sekaligus memberikan peran diri sebagai fungsi kontrol pengawas terhadap diri anak akan berbagai informasi yang diterima anak. Hal ini terutama pada usia golden age yaitu rentang usia 0 sampai 5 tahun, di mana anak belum memiliki pengetahuan dan pengalaman. Sehingga anak diharapkan mampu membedakan mana hal yang baik dan mana hal yang buruk.

3. Fungsi pedagogis

Artinya bahwa pendidikan keluarga memberikan fungsi warisan nilainilai yang berkaitan dengan aspek kepribadian anak. Tugas akhir pendidikan keluarga tercermin dari sikap, perilaku dan kepribadian anak dalam kehidupan sehari-hari yang ditampilkan ${ }^{6}$

Sementara itu dalam teori lain Berns mengemukakan, bahwa fungsi keluarga adalah a. Fungsi reproduksi; b.

${ }^{6}$ M. Syahran Jailani. (2014). "Teori Pendidikan Keluarga dan Tanggung Jawab Orang Tua Dalam Pendidikan Anak Usia Dini," Nadwa 8(2), hlm. 245-60.
Melaksanakan pendidikan dan sosialisasi di masyarakat; c. Membangun aturanaturan sosial; d. Melakukan tindakan ekonomi; dan e. Membangun dan mendukung proses perkembangan emosi anak. $^{7}$

Dalam konteks pendidikan keluarga pola hasil yang diberikan oleh orang tua terhadap anak memberikan dampak yang signifikan terhadap tumbuh kembang anak. Pola asuh ini dapat berdampak pada keberhasilan belajar anak di sekolah. Penelitian barnadib menunjukkan bahwa kelompok anak-anak yang IQ-nya rendah, ternyata cenderung mendapatkan perhatian yang rendah dari orang tua. Berarti perhatian orang tua berpengaruh terhadap prestasi belajar. Dengan demikian apabila orang tua mengasuh anak secara permisif, maka prestasi belajar anak cenderung rendah. Sebab mereka tidak memperoleh perhatian yang wajar dan cukup dari orang tuanya.

Dalam penelitian lain yang dilakukan oleh Sayono mengemukakan bahwa sikap orang tua yang melindungi anak secara berlebihan menyebabkan sikap anak menjadi: a) Kurangnya motivasi belajar; b) Pasif dan sering kali menjurus ke sikap neuritik; c) Merasa harga diri rendah; dan d) kurangnya kesanggupan untuk

\footnotetext{
${ }^{7}$ Robert M. Berns. (2007). Child, Family,
} School, Community Socilization and Support Thomson Corporation: United State. 


\section{Manajemen Pendidikan Keluarga...}

merencanakan sesuatu. Dengan demikian pola asuh yang permisif maupun otoriter tidak memberikan keuntungan perkembangan kepribadian bagi anak maupun perkembangan belajarnya. Dalam riset lain Haditono mengungkapkan, bahwa pola asuh otoriter menyebabkan anak menjadi penakut, kurang bergembira, dan semangat hidupnya rendah. Hal ini adalah dampak dari kinerja otak anak yang tidak bekerja secara maksimal. Akhirnya anak sulit berpikir dan bertindak kreatif. Anak cenderung kurang mandiri dan prestasi belajarnya menjadi rendah. ${ }^{8}$

Dalam konteks manajemen untuk mencegah terjadinya pertengkaran diberhentikan antara anggota keluarga atau paling tidak mengurangi dampak negatif yang ditimbulkan terhadap psikologi dibutuhkan teori-teori tentang manajemen konflik.

Pembimbingan dalam sistem keluarga juga diperlukan guna mencapai tujuan bersama pendidikan keluarga. Ayah sebagai seorang pemimpin pendidikan keluarga menjadi leader yang bertugas memberikan perintah, arahan serta petunjuk lainnya pada istri yang bersifat mempengaruhi dan menetapkan arah tindakan. Atas dasar itu, maka pendidikan keislaman dalam keluarga akan berjalan

${ }^{8}$ Agus Zainul Fitri. (2016). "Keluarga Sebagai Lembaga Pertama Pendidikan Islam," Jurnal Pendidikan Islam, 27(1), hlm. 21-34. baik, ayah dapat memberikan pengarahan kepada ibu dengan tepat untuk melaksanakan tugasnya. Di samping itu, efektivitas perintah juga harus disesuaikan dengan kondisi dan konteksnya. Hal lain yang harus diperhatikan adalah peran serta pihak-pihak dalam keluarga yang terkait dalam melaksanakan tugasnya masingmasing. Dan yang utama adalah kesadaran antar pihak untuk mencapai tujuan yang akan dicapai.

Jalinan hubungan yang baik antara ayah dengan ibu dan dengan anggota keluarga lain juga antar anggota merupakan hal yang mutlak yang harus dilakukan agar tugas ke pendidikan dalam keluarga berjalan lancar. Dalam melakukan perjalanan hubungan ada tiga hal yang harus diperhatikan antara lain:

1. Koordinasi, yaitu pelaksanaan atas aktivitas secara teratur untuk memberikan jumlah, waktu dan pengarahan pelaksanaan dengan tepat.

2. Integrasi, maknanya adalah penggabungan bagian-bagian menjadi satu kesatuan yang bulat dan utuh.

3. Sinkronisasi, adalah menyatakan berbagai aktivitas untuk melaksanakan secara berbarengan. ${ }^{9}$

9 Bahrun Ali Murtopo. (2017. "Manajemen Orang Tua Dalam Pendidikan 
Di samping hal tersebut, peran komunikasi juga penting utamanya untuk komunikasi timbal balik antara kedua orang tua dalam kelancaran proses pendidikan dalam keluarga. Komunikasi adalah proses interaksi atau hubungan saling pengertian satu sama lain dengan maksud agar dapat diterima dan dimengerti di antara sesamanya dengan jalan bisa dengan lisan atau tulisan.

Jika kita meneliti era saat ini adalah era milenial di mana salah satu karakteristik penting di zaman milenial ini ada implikasi Ayat-Ayat Pendidikan Keluarga terhadap conectivity. Saat ini masyarakat kita memiliki karakter Urban middle class milenial. Dalam karakter masyarakat ini ada tiga ciri utama yang menggambarkan karakteristik masyarakat.

1. Confidence. Orang-orang saat ini sangat percaya diri. Berani mengeluarkan pendapat bahkan tidak sungkan berdebat di depan publik.

2. Creative. Orang biasa berpikir Out the Box. Kaya akan ide dan gagasan dan mampu mengkomunikasikan ide dan gagasan tersebut dengan cemerlang.

Anak Keluarga Muslim (Studi Kasus di Wotbuwono, Klirong. 4 Keluarga)," AWLADY: Jurnal Pendidikan Anak 3(2) hlm. 58-82.
3. Connected. Terutama dalam komunitas yang diikuti, aktif berselancar di sosial media dan internet.

Karakteristik masyarakat tersebut menjadi ciri yang tidak terbantahkan di tengah masyarakat kita yang berulang. Keluarga sebagai ruang terkecil dalam proses pendidikan harus memberikan atmosfer yang dapat mengembangkan kepribadian anak. Anak seharusnya dapat tumbuh kembang sesuai dengan bakat yang dimiliki dan minat yang diinginkan. Pengembangan ini tanpa harus tercerabut dari akar-akar budaya dan nilai-nilai fundamental spiritual Ilahiyah agama.

\section{KESIMPULAN}

Banyak kajian tafsir yang memberikan perspektif yang berbeda terkait dengan AlQur'an Surat At-Tahrim Ayat 6. Masingmasing tafsir ini tentu memiliki konteks dan pendekatan masing-masing. Akan tetapi satu hal yang menjadi catatan utama, bahwa Al-Qur'an memerintahkan untuk menjaga keluarga dari api neraka.

Di tengah masyarakat kita yang sudah berubah menuju zaman milenial dibutuhkan pendekatan baru dalam pendidikan keluarga. Era keterbukaan saat ini harus disikapi dalam membangun sistem keluarga yang baik. Sehingga konsep keluarga ini dapat benar-benar 


\section{Manajemen Pendidikan Keluarga...}

menjadi penopang dalam pembangunan peradaban masyarakat Islam yang Madani.

\section{DAFTAR PUSTAKA}

Berns, Robert M. (2007). Child, Family, School, Community Socilization and Support. Thomson Corporation: United State.

Fitri, Agus Zainul. (2016). "Keluarga Sebagai Lembaga Pertama Pendidikan Islam.” Jurnal Pendidikan Islam, 27(1).

Izzan, H. Ahmad, dan S. Saehudin. (2012). Tafsir Pendidkan: Studi Ayat-Ayat Berdimensi Pendidikan. Jakarta: Pustaka Aufa Media.

Jailani, M. Syahran. (2014). "Teori Pendidikan Keluarga Dan Tanggung
Jawab Orang Tua Dalam Pendidikan Anak Usia Dini." Nadwa, 8(2).

Langgulung, Hasan. (1986). Manusia dan Pendidikan. Jakarta: Pustaka AlHusna.

Maraghi, Ahmad Mushthafa, K. Anshori Umar Sitanggal, Hery Noer Aly, dan Bahrun Abubakar. (1987) Terjemah tafsir Al-Maraghi. Semarang: C.V. Toha Putra.

Murtopo, Bahrun Ali. (2017). "Manajemen Orang Tua Dalam Pendidikan Anak Keluarga Muslim (Studi Kasus Di Wotbuwono, Klirong. 4 Keluarga)." AWLADY: Jurnal Pendidikan Anak 3(2).

Syihab, M. Quraisy. (2012). Tafsir AlMisbah, Pesan, Kesan, Keserasian AlQuran. Vol. 14. Jakarta: Lentera Hati. 